\title{
Online Brands and Social Media Communities How Brands Can Engage and Establish Relationships with Customers via Online Brand Communities
}

\section{Julio Viskovich*}

Thompson Rivers University School of Business and Economics, Canada

\begin{abstract}
Social Media is an interactive network that is Internet based and developed for the sharing and engaging purposes. Sharing can be of an idea, information, expression, career interest, or data like images, videos, or files etc. via the networks or virtual communities. Now days, social media communities defines the future of brand as young generation took deep interest into the low \& high involved communities. Social media use to create communities online are recognized as a vital aspect of a brand strategy, enabling business progression through a computer mediated marketing environment (CMME).

In comparison, there are far less studies conducted by researchers or analysts which look into the impact of social media on brands classed as 'luxury'. The survey conducted was designed to find correlation between brand image in technology-based marketing environments, and the use of social media, determining the impact it has. Taking numerous reliable perspectives from well-known literature sources, predominantly on the topics of information management, communication strategies and marketing, this chapter details the effect of social media on consumers' perceptions of luxury fashion brands. This analysis and research clarifies social media's influence on brand reputation, particularly in the sector of marketing alongside current technology.

The purpose of writing this paper is to develop community consequences, antecedents' conceptual framework, and branding of online communities with the help of virtual communities and brand communities by the integration of extant literature. The informative motive, social integration motive, entertainment motive, self-discovery motive, and social enhancement motive are the conceptual frameworks. Consequences of moral responsibility, shared rituals, and kind are the pillars of traditions among members of the all online community consequences.
\end{abstract}

Keywords: Brand communities; Brand image; Online communities; Social media; Low involvement; High involvement

\section{Introduction}

A brand community needs to be defined be exploring three different branded community models: traditional, social media-centric and a more innovative blend of online and offline that will provide different ideas about in the recent times, consumers have embraced the Internet and have supported the social media. The developments in social communication are increasing drastically and in market analyses have been going through changes. Social media eases the interaction among consumers, considering social media sites as an online application platform, enables customers relationship management between them. The luxury fashion sector has been heavily influenced by the use of social media marketing which has shaped both brand reputation and relationships with consumers. This research meets the objective of analyzing the impact of social media within a technological working environment, using a social constructivist perspective to look closely at consumers' brand awareness within interactive markets, breaking away from traditionally used qualitative data $[1,2]$.

Fans are those who are dedicated enthusiastic and devoted members of a team's fan base and because of this differentiation it's really important at least early on with a fan community to focus more on that she said of course. But as you'll see in just a moment you can develop fans that are the spectators or lurkers as we will call them. Raving fans you know a lot of them are going to want to vote for a player that you want to go to the All-Star Game. You could also have these challenges around creating videos fan videos for the team. You can have them participate and surveys.
The difference that social networks allow you to do versus traditional approaches is to hyper-target new or current customers including those that are connected to your competitors. You can email them and you can't really customize the experience, so you play by what Facebook or LinkedIn given you as tools to use and engage. That really the challenge with communities today is that they are at the mercy of the day-today changes the social networks decide to implement. Brands have grown engaged audiences of millions and have had their organic reach refrained to $1 \%$ to $5 \%$ in some cases.

Even if a customer has a strong affiliation with a company an organization or a sports team, it is difficult to hold costumers attention. You know before 1990 only eight channels could grab our attention right. You had events and direct fax direct mail or phone if you were company and if you had a lot of big marketing budget you could go TV radio print and display and now there are literally thousands of ways to get information and people get distracted easily you know because of so much that they have this little device that they hold their hand this mobile phone when they can get access to information 24/7.

*Corresponding author: Julio Viskovich, Thompson Rivers University School of Business and Economics, Kamloops, Canada, E-mail: jviskovich@tru.ca

Received October 15, 2018; Accepted November 14, 2018; Published November 26, 2018

Citation: Viskovich J (2018) Online Brands and Social Media Communities How Brands Can Engage and Establish Relationships with Customers via Online Brand Communities. J Account Mark 7: 299. doi: 10.4172/2168-9601.1000299

Copyright: @ 2018 Viskovich J. This is an open-access article distributed under the terms of the Creative Commons Attribution License, which permits unrestricted use, distribution, and reproduction in any medium, provided the original author and source are credited. 


\section{Six Successful Example Online Brand Community}

Following are some of the High Level online brands or communities that are participating the daily life of in very effective manners. It has been stated in 2006 by Nielson that participation of users can be analyzed by $90-9-1$ rule which reflects the stats as $90 \%$ of the members of online communities are lurkers, which $9 \%$ of them contribute sometimes and for the rest of time, they stay away. The last $1 \%$ users were found as high contributors and they participated a lot [3]. This $1 \%$ is the people who made an Online Brand as a successful and make it Big Brand among others [4].

Many successful sites which demonstrate this system regularly include forms or sections which prompt communication with users, encouraging discussion and conversation around interests. This differs from the use of Facebook or Twitter to grow social communities.

Based on this, the best six example of brand community are:
a) Lego ideas.
b) Made Unboxed.
c) Figment.
d) PlayStation community
e) Beauty talk
f) Harley owners group.

\section{a) Lego ideas}

Lego is an excellent example of a company which has combined people's passion for their products with an online community, using message boards as well as running competitions for users to design and submit their own ideas, sharing with others.

\section{b) Made unboxed}

Made unboxed gives users an understanding how Made's products appear in real-life. Providing inspiration to shoppers, Made found a gap in the market, creating a similar experience to in-store shopping, online. With consumers preferring to purchase furniture seeing the items in realistic settings, an online showroom enabled viewers to do this, ordering from the comfort of their own homes.

\section{c) Figment}

Figment is a social network-style community which brings value to its visitors. With a target userbase of 13-18 year old, areas to share opinions and creative content, users can submit their own stories, as well as enjoying others' creations.

\section{d) PlayStation community}

PlayStation's business model has successfully integrated gaming into many people's everyday lives through creating a gaming community who are also able to communicate and discuss gameplay.

\section{e) Beauty talk}

Beauty Talk was an invention which came around after masses of frequently asked questions were left on the website Sephora.com. It builds in the requirement for the unbiased perception in the world of beauty. The main reason of its popularity is it's incredibly useful for answering product-related queries.

\section{f) Harley owners group}

Tapping into bike enthusiasts' passion, Harley Davidson has created an exclusive members-only website which gives unique benefits. A close community, Harley Davidson owners were given the opportunity to make lifelong connections with people with similar interests, being proud of their lifestyle and organizing meet-ups on the Harley Owners Group.

\section{Low Involvement Product Brand Communities}

Low involvement product, brand, or community is a place that is not able to compete the other competitors. Only by few techniques, small modifications in mechanism and proper team work can bring low involvement products into the list of high involvement products. Impulse buying is when a purchase is made without prior intention, through a high level of involvement and usually brought about through effective marketing. The level of involvement is how personally significant or interested somebody is in consuming a product. (Services, 2018). Products which have low involvement are not often impulse purchases; however they can be at times. These are often items which are within lower price ranges and also do not bring much rick to the person if they buy the product and then realise it was a mistake [5].

The more the brand is active on Social Communities, the higher possibility it has to grow. The techniques are reasonably simple in this age of technology in which social engagements play a vital role in marketing strategies, product branding, branding factors, and in building the image of a product.

\section{High Involvement Product Brand Communities}

A high involvement brand often carries a high price tag, for example, a property, vehicle or collectible item. For this reason, if the purchase turns out to be a mistake, there is a high risk for the person who purchased it. This type of purchase is less common than low involvement products, with no routine interaction with these items. Instead, users regularly spend a long time considering various options, weighing up pricing as well as seeking to understand all additional benefits and guarantees [1].

An online brand ambassador revealed that brand communities launch several marketing strategies to keep the users active and be in touch for the purpose of high involvement. Usually we found that big brands or the brands with high involvement of consumers has always eye catching offers, discount coupons, and responsive behaviors towards the consumers who can be an user, client, customer, or visitor. People at higher positions in any organization know that customer is the most important figure among all stakeholders. As the customer decides either brand will go up or down so that high involvement communities are built by the brands to stay in touch with its potential consumers. This is how a brand becomes big or small. Every community user is restrictedly having an established connection. Here is the graphical representation as Principal communication relationships in brand communities (Figure 1) [6].

\section{Low \& High Involvement Brand Factors}

The brand is not of a high or low level, it's the active users who made an online brand to be famous or flop. There are several key factor, based on what a social community becomes successful or failed. For example, there are two communities and both of them are having 100k active users but the activities in a community $\mathrm{A}$ is very low and it rarely reach to the $2 \mathrm{k}$ but on the other hand community $\mathrm{B}$ has most of the active users who made it distinct from others and keep it in high involvement range. The admins or stakeholders of any community also provide the base to the community for initiating the directions for future. 


\section{Best Practices for Online Brand Communities}

Branded online communities need to hold fan interest and drive advocacy on behalf of the brand but not like those old communities and even the commonly used social media communities. Brands have to do something even more unique and special way that holds their audience's attention and also keeps them engaged. Why? Because they need to be incentivized to contribute. Brand fans want to be recognized if they're helping your team or your organizations. But most people feel like if you're rewarding your fans for participating in your community they need to be financially rewarded.

Brand advocates or community members do not need to be financially rewarded and this is why the majority of organizations can't hold or sustain a community even though there is never been more options that are out there. There are numerous explanations for this. Typically because businesses have been playing by someone else's rules that determine what can and can't occur within brand community. Typically there are not many great things in the community to hold your fan interest. Thus, brands need to look at their strategy differently. We need to take what's worked in the past and add that to what's working now.

This is where value comes in. Imagine building a branded community that you could control and that has all the features built into it. One that keeps your fan base engaged in advocating on your behalf because you because primarily you've figured out a way to deliver its great value to them on a regular basis so when you look at.

\section{Motivations for Consumers to join Online Brand Com- munities}

Consumers Motivation is much necessary for a brand to build it as Big, to involve the consumers in the brand, and to engage people with interesting deals is a key to success for Online brand Communities. Generally four motivations exists based on what consumers might join the community, all these four are discovered after reviewing a lot of literature. Following are the four motivations:

- Reassurance of quality and credence attributes

- High involvement with the branded product category

- Opportunity for joint consumption

- The brand's symbolic function

First of all, Quality reassurance can lead the brand community participation to the next level. It means the product should be classified as per credence quality, search, and experience to obtain the quality products. Brand communities are a sort of potential consumers group looking for credence product quality [7].

Secondly, a true consumer will always make an extensive search for the high-involvement product. That means quality can't be compromised when a group of potential consumers is going to take your services order.

Third point is Joint Consumption that means goods that can be consumed publically. As it can be sports, games, and board games etc.

Forth, brand symbolic function or brand identity. That gives a clear idea of the product or business as what's people are going on these platforms. Below is a representation of given four Motives and their Dominant relationships for better understanding in graphical form Table 1.

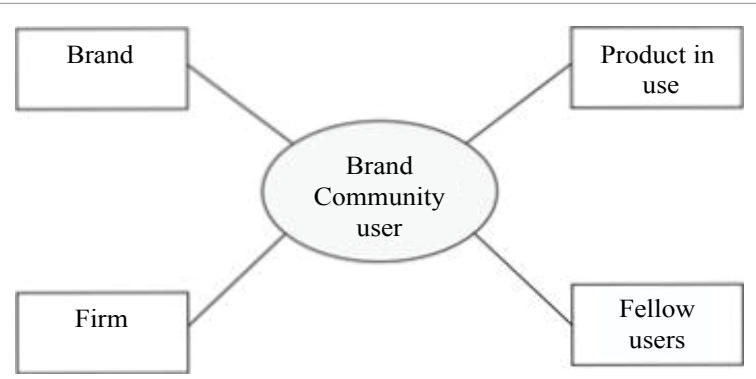

Figure 1: Principal communication relationships in brand communities.

\begin{tabular}{|c|c|}
\hline Motive & Dominant Relationship \\
\hline Assurance for credence good & Customer-company relationship \\
\hline High involvement in product category & Customer-product relationship \\
\hline Joint consumption & Customer-customer relationship \\
\hline Brand symbol & Customer-brand relationship \\
\hline
\end{tabular}

Table 1: Motives and their dominant relationships.

\section{The Brand is Not of Conclusion}

With the continuous progression and growth in the interest and use of social media platforms, brands are always looking to grow their presence, creating dedicated followings or communities which can share and interact with content to increase brand reach and success. This quickly expanding user base interact regularly and often using handheld devices, also seeing contributions on brands' online communities growing.

There are often debates surrounding the influence social media platforms have on branding, with many experts looking into the system as opposed to campaign objectives, sometimes hindering the ability to get a clear idea of their benefits on a business.

For example, many believe that social media creates the opportunity for companies to successfully promote any brand, service or product. On the other hand, there are still some who state that social media is only useful to communicate with friends and people you already know. This analysis demonstrates numerous contributors, all of whom are familiar with social media platforms. Developing marketing strategies which encompass social media greatly benefits sellers. Luxury fashion brands benefit particularly through the use of creating online communities, with discussion and online interaction providing endless benefits.

In addition, the implementation of brand and online communities enable managers and marketers to create marketing plans, designed to reach and entice potential new consumers through these platforms.

\section{References}

1. Ansarin M, OzuemW (2015) Social Media and Online Brand Communities.

2. Zaglia EM (2013) Brand communities embedded in social networks. J Bus Res 2: 216-223.

3. Nielson J (2006) Participation inequality: Encouraging more users to contribute

4. Gilliland N (2017) Six successful examples of online brand communities.

5. Mangold GW (2009) Social media: The new hybrid element of the promotion mix. Business Horizons 52: 357-365.

6. Research Services (2018) Consumer Behaviour Studies: High-Involvement versus Low-Involvement.

7. Xiang Z, Gretzel U (2010) Role of social media in online travel information search. Tourism Manage 31: 179-188. 